\title{
Uncertainties in Dimensional Measurements Made at Nonstandard Temperatures
}

\section{Dennis A. Swyt}

National Institute of Standards and Technology, Gaithersburg, MD 20899-0001
This report examines the effects of uncertainties in temperature and coefficient of thermal expansion on the expanded uncertainty of length dimensjonal theasurcments made away from the international standard referesce temperature of $20^{\circ} \mathrm{C}$ lor artifact standards and workpieces of various materiats. Specific cases cxamined deal with: 1) uncertainties of thermal-expansion coefficients associated with values given in enginecring references, standard reference data, standard teference materials and direct measurements; and 2) uncertaintics of part temperature mea- sturements associated with realizing the Internationa! Temperature Seale of 1990 (ITS-90) and determining part temperatures relative to ITS-90 with the prituipal types of themametry and achievabie levels of temperature control.

Key words; dimensional measurement; dimensional tolerances; length metrology; measurement uncertainty; reforence temperature; thermal expansjon.

Accepled: Norember 1, 1993

\section{Introduction}

Material objects-whether complex-geometry parts designed to fit into assemblies or simple-geometry artifacts designed to be calibrated as standards of length - have dimensions which vary with temperature. The size of the variation depends upon the specific material. For example, for aluminum, stecl, and silicon, typical coefficjents of thermal expansion are respectively, in units of parts per million per degree Celsius, $23.1 \mathrm{ppm} /{ }^{\circ} \mathrm{C}, 11.5$ $\mathrm{ppm} /{ }^{\circ} \mathrm{C}$, and $2.6 \mathrm{ppm} /{ }^{\circ} \mathrm{C}$.

Because of the effects of thermal expansion, by national and international agreements lengthbased dimensions-including those specified, for example, on engineering drawings - are defined to be those which exist at a standard reference temperature of $20^{\circ} \mathrm{C}[1,2]$.

Figure 1 illustrates one of two recent developments which have made the issue of thermal-ex- pansion effects in part melrology a matter of increased concern. The figure shows the on-going trend in the manufacture of discrete-part products to increasingly tighter dimensional tolerances in state-of-the-art manufactured goods from aircraft and automobiles to computers and electronics [3]. According to this trend, such tolerances have been decreasing in size by a factor of approximately three every ten years, so that there are today, for example, automobile pistons with tolerances of 6 $\mu \mathrm{m}-7 \mu \mathrm{m}$ and quantum-well electronic devices with tolerances of $0.5 \mathrm{~nm}$ [4].

The second development is a proposal to the International Organization for Standardization, subsequently unadopted but of technical import, to change the international standard reference temperature for dimensional measurements from $20^{\circ} \mathrm{C}$ to $23^{\circ} \mathrm{C}$ [5]. Since referring measurements to a 


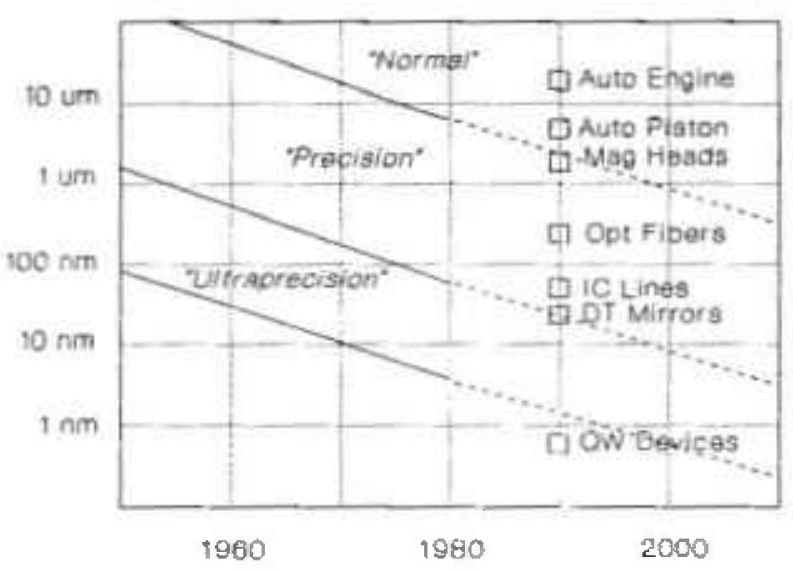

Fie 1. Trends and examples of state-of-art in dimension tolernces of manufactured parts in normal, precision, and ultrprecision regimes,

standard temperature serves to reduce actual variations in dimensions of parts due to thermal-expansion effects as well as uncertainty in measurements, a shift in reference temperature can increase each, that is, both variations and uncertainties.

This paper looks at possible errors and likely uncertainties in dimensional measurements due to thermal-expansion effects where those measurements are made away from the reference temperature, either the specific interval of $3^{\circ} \mathrm{C}$ due to a change to the proposed $23^{\circ} \mathrm{C}$ or an arbitrary interval due, for example, to the settling of a temperature control system at other than the standard reference temperature.

\section{Uncertainties Due to Thermal Expansion}

Contributions to uncertainty in measurements of length-based dimensions due to measurements made at nonstandard temperatures are a function of the length of the object being measured, its temperature, its coefficient of thermal expansion, and the uncertainties in each of these quantities.

The coefficient of linear thermal expansion (CTE) of a material, $\alpha$, is defined to be

$$
\alpha(T)=\frac{\mathrm{d} L / L}{\mathrm{~d} T},
$$

where $\mathrm{d} L / L$ is the fractional change in a characteristic linear dimension and $\mathrm{d} T$ is the change in temperature. For a sample with length $L_{0}$ at temperature $T_{b}$ the length $L$ at temperature $T$ is found by integration to be

$$
L=L_{0} \exp \left[\int_{r_{i}}^{T} \alpha(T) \mathrm{d} T\right]
$$

If $\alpha(T)$ is assumed to vary only slightly over the temperature range $T-T_{0}$, it may be replaced by an average value $\alpha$ and $\mathrm{Eq}$. (2) becomes

$$
L=L_{0} \exp \left[\alpha\left(T-T_{0}\right)\right] \text {. }
$$

For typical materials and for changes of temperatures from room temperature to their melting points, Eq. (3) is approximated to within less than $1 \%$ by

$$
L=L_{0}\left[1+\alpha\left(T-T_{00}\right)\right]
$$

Equation (4) is the standard expression used to correct dimensional measurements made at a uniform temperature other than the one desired.

\section{Uncertainties and Error Relative to Tolerances}

This report will use two different methods for examining the effects of thermal expansion relative to tolerances of measurements made at nonstandard temperatures. The first method follows the recommended practice of an international standards body and deals with propagated uncertainties. The second method follows the recommended practice of a national standards body and deals with estimated maximum error. Each method compares resulting uncertainties to a tolerance, that is, to a specified limit of permissible error.

\subsection{Thermal Uncertainty Index (TUI)}

The first method-which is based upon the approach recommended by the International Committee for Weights and Measutes (CIPM), which is the basis of a guideline published by the International Organization for Standardization, and which has been adopted as NIST policy - uses root-sumof-squares (RSS) propagation of uncertainty [6]. In this approach, the combined standard uncertainty associated with the correction for thermal expansion given by Eq. (4) is the positive square root of the estimated variance $u_{\mathrm{e}}{ }^{2}$ given by

$u_{\mathrm{c}}=\sqrt{\left(\frac{\partial L}{\partial T}\right)^{2} u_{T}^{2}+\left(\frac{\partial L}{\partial \alpha}\right)^{2} u_{m}^{2}}$

where there is assumed to be no correlation between the variations in temperature and the varia- 
tions in the coefficients of thermal expansion. Following the CIPM approach, in this first method results are expressed as an expanded uncertainty:

$$
U=k \cdot u_{\varsigma},
$$

with $U$ determined from a coverage factor $k$ and the combined standard uncertainty $u_{c}$, the estimated standard deviation given by Eq. (6). To be consistent with current international practice, the value of $k$ used by NIST for calculating $U$ is, by convention, $k=2$ [7]. Hence, with partial derivatives from Eq. (4), substitution of Eq. (5), and $u_{T_{0}}=0$, Eq. (6) becomes

$$
U=2 \cdot u_{c}=2 \sqrt{\left(\alpha L_{0} \mu_{T}\right)^{2}+\left(u_{\alpha} L_{0}\left(T-T_{0}\right)\right)^{2}} .
$$

In parallel with the method to be described in the next section, this paper defines a ratio of expanded uncertainty to tolerance, that is, the limit of permissible error, called the Thermal Uncertainty In$\operatorname{dex}(T U I)$ :

$$
T U I=(U / \tau) \times 100 \%,
$$

where $U$ is the expanded uncertainty defined by Eq. (7) and $\tau$ is an engineering tolerance specific to a given situation.

\subsection{Thermal Error Index (TEI)}

The second method, based on the approach recommended by the American National Standard Institute (ANSI) in its standards dealing with environmental conditions for dimensional measurements, involves linear addition of absolute values to estimated limits of error [2]. In this approach, the estimated worst-case limit of error $e_{c}$ associated with the correction for thermal expansion given by Eq. (4) is

$$
e_{c}=\left|\frac{\partial L}{\partial T}\right| e_{T}+\left|\frac{\partial L}{\partial \alpha}\right| e_{a}
$$

which, with partial derivatives from Eq. (4), becomes

$$
e_{\mathrm{c}}=\left|\alpha L_{0}\right| e_{T}+\left|L_{0}\left(T-T_{0}\right)\right| e_{\alpha}
$$

where $e_{T}$ and $e_{a}$ are worst-case errors in temperature and themal-expansion coefficients and the terms proportional to each are the errors in the correction for thermal expansion due respectively to nominal differential expansion and the temperature variation.

In the ANSI standard which specifies the temperature conditions for dimensional measurements, Thermal Error Index $(T E I)$ is defined and represented formally by:

$$
T E I=[(T V E+U N D E) / W T] \times 100 \% \leqslant 50 \%,
$$

where $T E I$ is the thermal error index, UNDE is the stated uncertainty (no further specification) of nominal differential expansion times the temperature difference, TVE is a temperature variation error (defined by a maximum range of temperature drift), and $W T$ is the working tolerance for a specific test. According to ANSI-standard procedures for evaluating the performance of dimen. sional measuring machines, the $T E I$ should be less than $50 \%[8]$.

The parallelism of the two terms of the Thermat Error Index given by Eq. (11) with those of the variational form of thermal-expansion errors on length given by Eq. (9) suggests that a useful basis for estimating the significance of thermal-expansion effects in dimensional measurements in a specific situation is to determine whether the ANSI-specified condition on TEI is met, that is, whether the worst-case limit of error defined by Eq. (10) meets the following condition:

$$
e d \tau \leqslant 1 / 2
$$

where $W T$, the symbol for the working tolerance used in the standard, has been replaced by $\tau$, the symbol for the specified tolerance introduced in the definition of Thermal Uncertainty Index defined in Eq. (8).

\subsection{Interpretation of Statements of Accuracy, Uncertainty, and Error}

This report follows the NIST policy on statements of uncertainty associated with measurement results which gives procedures for combining various statements of accuracy, uncertainty and limits of error from other sources, including published measurement data, manufacturer's specifications, data in calibration and other reports, and reference-data handbooks [9].

Throughout this report, unless otherwise noted, unqualified statements of accuracy, uncertainty and limits of error that are taken from other sources are indicated as "stated uncertainty" (des- 
ignated in Tables by the symbol $\Delta$ ) and discussed as such, but, when combined, are converted to the standard-uncertainty representation by assuming a uniform or rectangular probability distribution with

$$
U=2 u=\frac{2}{\sqrt{3}} a=1.155 a,
$$

where $a$ is the stated accuracy, uncertainty or estimated limit of error in the reported source and the half width of the assumed distribution. Thus a value given in some source as " $Y \pm X \%$ " is quoted here as a stated uncertainty of $X$ but when combined to give an expanded uncertainty is repre. sented as " $Y \pm 1.155 \times X \%$." Note for comparison that this method of conversion to an expanded uncertainty yieids a result which is within $15 \%$ of both the unqualified original statement and a value reported at the $95 \%$ level of confidence, which is converted to the $2 \sigma$ expanded uncertainty by multiplication by $2 / 1.96$, but is that much outside the assumed uniform distribution and is, therefore, non-physical. Note, however, that since both are so converted, the ratio of the uncertainty to a tolerance is the same whether in the stated or expanded forms.

\section{Uncertainties Due to Variations in Coefficient $\alpha$}

An uncertainty in measurement results from uncertainty in the particular value of the CTE, $\alpha$, used to calculate a part's dimension at the refer. ence temperature when measurements are made at another temperature. The uncertainty in the nominal CTE, while seldom considered in conventional dimensional metrology, has long been recognized as important for large parts (large $\alpha L_{0}$ ) and for large temperature extrapolations (large $T-T_{0}$ ) $[2,10]$. Due to the trends which have made micrometer and nanometer tolerances more commonplace, errors and uncertainties due to thermalexpansion effects are now an important consideration for part sizes and temperature extrapolations not previously considered large.

\subsection{Range of Reference Values of $\alpha$}

Table 1 shows the variety of values of CTEs of some metrologically important materials that can be found in references including handbooks for en: gineers, machinists, and material scientists. Among the materials are: the elements aluminum, iron, and silicon; specific alloys such as Al 6061 and stainless steel 304; general alloys such as cast iron and carbon steel; common Pyrex (a borosilicate

Tuble 1. Variety of values of crefficicnts of thermal expansion (in ppm/ $/ \mathrm{C}$ ) of some metrologically-important materials provided in various engineering references

\begin{tabular}{llllll}
\hline Material & CRC [11] & MHB [12] & MSO [13] & ASM [14] & TPM [16] \\
\hline A! & 25 & 22.4 & & 23.6 & 23.1 \\
Al 6061 & & & 22.0 & 23.4 & 22.5 \\
SS 304 & 17.3 & & $10.6-17.8$ & 17.2 & 14.7 \\
BeCu & 16.7 & & & & 16.2 \\
Fe & 12 & & & 11.7 & 11.8 \\
Cast iron & 13.5 & 11.8 & $10.6-18.7$ & $8.1-19.3$ & 11.9 \\
C-Steel & 12.1 & 11.4 & $13.5-15.2$ & $11.6-12.6$ & 10.7 \\
Pyrex & 3.2 & & & 3.2 & 2.8 \\
Silicon & 3 & & 4.67 & 5 & 2.6 \\
Fused quartz & 0.42 & & 0.56 & 0.55 & 0.49 \\
Invar & & & & $0.64-2.0$ & 0.13 \\
Zerodur [12] & & & & & 0.05 \\
\hline
\end{tabular}

"Source identifies stainless stecls only by type, e.g. austenitic, ferritic, and age-harden" able.

\footnotetext{
${ }^{\mathrm{I}}$ Certain commercial equipment, instruments, or materials are identified in this paper to specify adequately the experimental procedure. Such identification does not inply recommendation or endorsement by the National Institute of Standards and Technology, nor does it imply that the materials or equipment identified are necessarity the hest available for the purpose.
} 
glass) and low-expansion materials, including vitreous silica (fused polycrystalline quartz) and $\mathrm{Ze}$ rodur (a mixture of crystalline and polycrystalline quartz) [11-17]. Inspection of Table 1 shows the problem of determining a value of CTE for a specific object by looking up a value for a material, namely the variety of values likely to be encountered.

Variations among the values for the various materials from the references shown in Table $1 \mathrm{in}$. clude, for example, $4.5 \mathrm{ppm} / \mathrm{C}$ or $35 \%$ of the mid-range value for carbon steel, $7.0 \mathrm{ppm} /{ }^{\circ} \mathrm{C}$ or $50 \%$ of the mid-range value for the stainless steel (which includes CTEs for SS-301 and others from a reference which gives CIEs only for generic types of SS), and $11.2 \mathrm{ppm} /{ }^{\circ} \mathrm{C}$ or $75 \%$ of the mid-range for cast-iron.

Table 2 illustrates some likely causes for such variations in tabulated values of CTEs, with the $35 \%$ range of the extremes from the mid-value CTE encountered for carbon steel taken as an example. As with other materials, these causes of variations are differences in chemical composition. the physical processing to which the specific sample has been subjected, and the value or range of temperatures for which the coefficient is specified.

The first likely cause of differences in reported values of CTEs for nominally the same material is differences in chemical composition. In general, the name carbon steel encompasses a range of carbon concentration from a few tenths of one percent to nearly $1.5 \%$ and includes various small amounts of other elements such as $\mathrm{Mn}, \mathrm{P}, \mathrm{S}, \mathrm{Si}, \mathrm{Cr}, \mathrm{Ni}$, or Mo, with the values of CTE of annealed samples of carbon steels reported by one source ranging from $11.1 \mathrm{ppm} /{ }^{\circ} \mathrm{C}$ to $12.6 \mathrm{ppm} / / \mathrm{C}$ depending on composition [14].

The second likely cause of differences in reported values of CTEs for nominally the same material is differences in microstructure associated with the physical processing to which the sample of material has been subjected. These processes include combinations of mechanical working and heat treatment, such as hot rolling, cold rolling, drawing, casting and annealing. For example, the range of variation of the CTE of steel has been reported to be $\pm 2 \%\left(0.2 \mathrm{ppm} /{ }^{\circ} \mathrm{C}\right)$ anong samples cut from different locations in a large piece of steel that has been fully annealed, $\pm 3 \%\left(0.3 \mathrm{ppm} /{ }^{\circ} \mathrm{C}\right)$ among many heats of nominally the same chemical content, $=5 \%(0.5 \mathrm{ppm} / \mathrm{C})$ between hot and cold rolling, and $\pm 10 \%\left(1.1 \mathrm{ppm} /{ }^{\circ} \mathrm{C}\right.$ ) among several heat treatments [18]. For the carbon steel (AISI 52100 ) of gage blocks, the annealed and hardened states of the material have reported CTEs $\left(20^{\circ} \mathrm{C}\right.$ to $100^{\circ} \mathrm{C}$ ) of $11.9 \mathrm{ppm} /{ }^{\circ} \mathrm{C}$ and $12.6 \mathrm{ppm} /{ }^{\circ} \mathrm{C}$, respectively [15].

In the case of Invar, Table I shows a range of values of CTE from 0.13 to $2.0 \mathrm{ppm} / \mathrm{C}$ for various types of mechanical working and heat treating. Such processing can increase or decrease CTEs and can yield positive, negative or zero values, each of which can vary with time. As indicated by Table 3, annealing of Invar can increase the CTE and quenching can decrease it. Cold working after quenching can reportedly produce a negative coefficient, with very low CTEs usually reverting with time to the normal value for the material [15].

The third likely cause of differences in reported values of CTEs for nominally the same material are differences in the values or range of temperatures for which the CTEs are given. Among the sources cited here the most typical situation is an average value for a range of temperature from $20^{\circ} \mathrm{C}$ up to $100^{\circ} \mathrm{C}$ or as much as $1000^{\circ} \mathrm{C}$. That such average values can be significantly different than the $20^{\circ} \mathrm{C}$ standard-temperature value is shown by Table 4 , which compares with its $20^{\circ} \mathrm{C}$ value the mean CTE for the range $20^{\circ} \mathrm{C}$ to $107^{\circ} \mathrm{C}$ and also shows the temperature derivative of the CTE at $20^{\circ} \mathrm{C}$ in both

Table 2, Varicty of values of the coefficient of thermal expansion (CTE, in ppm/ C) of carbon steel reported in various sources

\begin{tabular}{|c|c|c|c|c|c|}
\hline MHB [12] & CRC [11] & MSG [13] & ASM-1 [15] & ASM-2 [14] & TPM [10] \\
\hline Stcel, carbon & $\begin{array}{l}\text { Plain cabon } \\
\text { sted } \\
\text { AISI-1020 } \\
\text { Typical 12.1 }\end{array}$ & $\begin{array}{c}\text { Carbon stecl } \\
\text { hardening grades } \\
\text { wrotght } \\
T=21^{\circ} \mathrm{C}-649^{\circ} \mathrm{C} \\
135-14.9 \\
\text { Carbon steel } \\
\text { carburizing grades } \\
\text { wrought } \\
T=21^{\circ} \mathrm{C}-649^{\circ} \mathrm{C} \\
15.2\end{array}$ & $\begin{array}{c}\text { AISI grade } \\
1020(0.22 \% \mathrm{C}) \\
T=20^{\circ} \mathrm{C}-100^{\circ} \mathrm{C} \\
11.7 \\
\text { AlSI grades } \\
1070-1085 \\
T=200^{\circ} \mathrm{C}-100^{\circ} \mathrm{C} \\
11.0-11.8\end{array}$ & $\begin{array}{c}\text { Fe-C alloy } \\
1.08 \% \mathrm{C} \\
T=20^{\circ} \mathrm{C}-100^{\circ} \mathrm{C} \\
10.8 \\
\text { Fe-C alloys } \\
1.45 \% \mathrm{C} \\
T=20^{\circ} \mathrm{C}-100^{\circ} \mathrm{C} \\
10.1\end{array}$ & $\begin{array}{c}\text { Carbon steel } \\
\text { Fe }+(0.7-1.4) \% \mathrm{C} \\
\text { well-annealed } \\
T=20^{\circ} \mathrm{C} \\
10.7 \pm 0.7\end{array}$ \\
\hline
\end{tabular}


Toble 3. Effects of heat treatment and mechanical processing on the mean thermal expansion of liwar $\left(T=16^{\circ} \mathrm{C}-100{ }^{\circ} \mathrm{C}\right)$

\begin{tabular}{lc}
\hline \hline Processing & Mcan a (ppri//C) \\
\hline Oucnched cold-drawn & 0.14 \\
Annealed quenched & 0.5 \\
Hol mitl & 1.4 \\
Forged & 1.7 \\
$19 \mathrm{~h}$-coul from $830^{\circ} \mathrm{C}$ & 2.0 \\
\hline
\end{tabular}

a ppm $/\left({ }^{\circ} \mathrm{C}\right)^{2}$ and $\% / \mathrm{C}$ form $[16,17]$. Note that for some materials the difference between the CTE at $20^{\circ} \mathrm{C}$ and an average value, such as that for the range $20^{\circ} \mathrm{C}-107^{\circ} \mathrm{C}$ shown, can be substantial, including $1 \mathrm{ppm} /{ }^{\circ} \mathrm{C}(5 \%)$ for aluminum and its alloys, $0.5 \mathrm{ppm} / \mathrm{C} \mathrm{C}(20 \%)$ for silicon, and $0.43 \mathrm{ppm} /{ }^{\circ} \mathrm{C}$ $(300 \%)$ for Invar.

A further consideration in assigning a value of CTE to a particular object is whether the material of the object is homogenous. An obvious situation is that of a compound object, that is, an assembly consisting of materials with different coefficients. One example of such is a commercial ball-plate for performance evaluation of coordinate measuring machines, which consists of ceramic balls mounted in a steel plate [19]. Less obvious is the situation of casehardened parts, where the surface to some depth has a different CTE than that of the interior. Due to such inhomogeneities, measured values of CTE for steel gage blocks have been observed to be length-dependent, ranging from an asymptotic 12.0 $\mathrm{ppm} / \mathrm{C}$ for lengths less than $50 \mathrm{~mm}$ to an asymptotic $10.6 \mathrm{ppm} /{ }^{\circ} \mathrm{C}$ for lengths greater than $500 \mathrm{~mm}$, with a value of $11.5 \mathrm{ppm} /{ }^{\circ} \mathrm{C}$ for lengths near $100 \mathrm{~mm}$ [20].

\subsection{Uncertainty in Spectic Values of a}

Given that the CTE of an object depends upon it: homogeneity, chemical composition, history of ther. mal-mechanical processing (such as heat treatment cold working, and hardening), and temperature, a basis for estimating the degree to which even wellcharacterized values of CTE are known is given by Table 5, which shows the stated uncertainties in CTEs for some calibration artifacts, standard reference data and standard reference materials.

As indicated in the first row of Table 5 , the American National Standard ANSI/ASME B89.1.2 for gage blocks specifies that the CTEs of gage blocks conforming to the standard are stated to be "accurate to within $\pm 10 \%$ of value stated for the blocks between $15^{\circ} \mathrm{C}$ and $30^{\circ} \mathrm{C}$ '" [21]. The paralle! international standard specifies that the CTE of steel gage blocks in the temperature range $10^{\circ} \mathrm{C}$ and $30^{\circ} \mathrm{C}$ be within the limits $(11.5 \pm 1.0) \mathrm{ppm} /{ }^{\circ} \mathrm{C}$, an $8.7 \%$ tolerance [22].

Shown in the second row of Table 5 are the stated values of uncertainty specified with standard-reference-data values of CTE for materials covering a wide range of values [16]. As indicated by Table 5 . typical reported uncertainties for what are averages over a number of well-annealed samples of specificcomposition alloys are $5 \%$ and $7 \%$.

In the third row of Table 5 are the stated uncertainties assigned to the values of CTEs of standard reference materials produced and sold as standards of thermal expansion for use in calibrating dilatometers [23]. As indicated, the stated uncertainty associated with each of these specific well-annealed samples of specific-composition reference materials is $\pm 0.03 \mathrm{ppm} /{ }^{\circ} \mathrm{C}$, which for materials such

Table 4. Calculated remperature-average $\left(20^{\circ} \mathrm{C}-107^{\circ} \mathrm{C}\right)$ and temperature derivatives $\left(20^{\circ} \mathrm{C}\right.$ ) of therma! expansion coefficients (CTEs) for some metrologically important materials $[11,12]$

\begin{tabular}{|c|c|c|c|c|}
\hline Matcrial & $\begin{array}{c}a_{-\sigma}\left(20^{\circ} \mathrm{C}-107^{\circ} \mathrm{C}\right) \\
\left(p \mathrm{pm} /{ }^{\circ} \mathrm{C}\right)\end{array}$ & $\begin{array}{l}a\left(20^{\circ} \mathrm{C}\right) \\
\left(\mathrm{ppm} /{ }^{\circ} \mathrm{C}\right)\end{array}$ & $\begin{array}{l}(\mathrm{d} a / \mathrm{d} T)_{n+\mathrm{C}} \\
{\left[\mathrm{ppm} /\left({ }^{\circ} \mathrm{C}\right)\right]^{2}}\end{array}$ & $\begin{array}{c}(\mathrm{da} / \mathrm{adT}) \\
(\% / F \mathrm{C})\end{array}$ \\
\hline Aluminum & 24.2 & 23.1 & 0.009 & 0.04 \\
\hline A1 6061 & 23.7 & 225 & 0.023 & 0.10 \\
\hline $\mathrm{BcCu}$ & & 16.2 & av $0.009 \mathrm{gm}=$ & 0.06 \\
\hline Cast iton & 120 & 11.9 & 0.0088 & 0.07 \\
\hline C-steel & 11.9 & 30.7 & 0.018 & 0.17 \\
\hline Ovartz & 11.7 & 10.3 & 0.023 & 0.22 \\
\hline Pyrex & 3.4 & 2.8 & 0.00083 & 0.03 \\
\hline Silicon & 3.1 & 2.6 & 0.0031 & 0,12 \\
\hline Fused quartz & 0.60 & 0.49 & 0.00032 & 0.117 \\
\hline Invar & 0.56 & 0.13 & 0.012 & 9.2 \\
\hline Zeradur & 0.05 & $<0.05$ & $<0.0015^{2 x-3 M_{1}}$ & \\
\hline
\end{tabular}


Table 5. Comparison of the stated uncertainties in coefficients of thernal expansions associated with various standard gagcs, data, and materials

\begin{tabular}{|c|c|c|c|c|}
\hline Specifier & Matcrial & $\underset{(\mathrm{ppm} / / \mathrm{C})}{\alpha}$ & $\begin{array}{l}\Delta_{a} / \alpha \\
(\%)\end{array}$ & $\begin{array}{c}A_{x} \\
(\mathrm{ppm} / \mathrm{C} C)\end{array}$ \\
\hline $\begin{array}{l}\text { ANSI standard for } \\
\text { gagc blocks [22] }\end{array}$ & $\begin{array}{l}\text { Stainless stcel } \\
\text { Cr-plated steel } \\
\text { Chrome carbide } \\
\text { Tungsten carbide }\end{array}$ & $\begin{array}{c}\text { To be } \\
\text { stated by } \\
\text { manufacturer } \\
\text { of G-blocks }\end{array}$ & $\begin{array}{l} \pm 10 \% \text { of } \\
\text { stated } \\
\text { value }\end{array}$ & $\begin{array}{l}1-1.5 \\
1.1 \\
0.8 \\
0.4\end{array}$ \\
\hline $\begin{array}{l}\text { TPM standard } \\
\text { reference data [17] }\end{array}$ & $\begin{array}{l}\text { Aluminum } \\
\text { Al } 6001 \\
\text { Carbout steel } \\
\text { Silicon } \\
\text { Fused quartz }\end{array}$ & $\begin{array}{c}23.1 \\
22.5 \\
10.7 \\
2.6 \\
4.49\end{array}$ & $\begin{array}{l}3 \% \\
7 \% \\
7 \% \\
5 \% \\
5 \%\end{array}$ & $\begin{array}{l}0.7 \\
1.6 \\
0.75 \\
0.13 \\
0.025\end{array}$ \\
\hline $\begin{array}{l}\text { NiST standard } \\
\text { refercnce matls [24] }\end{array}$ & $\begin{array}{c}\text { Copper } \\
\text { SS-446 } \\
\text { BS-glass } \\
\text { Fused } \mathrm{SiO}_{2}\end{array}$ & $\begin{array}{r}16.64 \\
9.76 \\
4.78 \\
0.48\end{array}$ & $\begin{array}{l}0.18 \% \\
0.31 \% \\
0.63 \% \\
6.3 \%\end{array}$ & $\begin{array}{l}0.03 \\
0.03 \\
0.03 \\
0.03\end{array}$ \\
\hline $\begin{array}{l}\text { NRLM dilatometer } \\
\text { results [25] }\end{array}$ & $\begin{array}{c}\text { Duraluminum } \\
\text { Copper } \\
\text { C-stcel }(0.55 \%) \\
\text { Invar } \\
\text { Glass ceramic }\end{array}$ & $\begin{array}{r}23.129 \\
16.556 \\
11.314 \\
0.351 \\
0.000\end{array}$ & $\begin{array}{l}0.37 \% \\
0.33 \% \\
0.36 \% \\
2.0 \%\end{array}$ & $\begin{array}{l}0.086 \\
0.055 \\
0.038 \\
0.007 \\
0.006\end{array}$ \\
\hline
\end{tabular}

as steels with coefficients of the order of $10 \mathrm{ppm} /{ }^{\circ} \mathrm{C}$ corresponds to approximately $0.3 \%$.

Finally, in the fourth row of Table 5 are the stated uncertainties of recent dilatomerer measurements by a national standards laboratory on a range of materials, including, for example, one of the standard reference materials shown in the third row [24]. As indicated, the reported uncertainties for each of these materials vary from a high of 0.086 down to a low of $0.006 \mathrm{ppm} / \mathrm{C}$. Representative of the stated uncertainties in the CTEs of these standard reference materials is the $0.36 \%$ value for the materials other than the zero-expansion glass-ceramic.

Taken together, Tables 1, 2, and 5 provide a basis for some generalizations about the expanded uncertainties of values of CTEs: First, with no further information about composition or history, the expanded uncertainty of the CTE for materials simply described as carbon steel, stainless steel or cast iron can be from $5 \mathrm{ppm} /{ }^{\circ} \mathrm{C}$ to greater than 10 $\mathrm{ppm} /{ }^{\circ} \mathrm{C}$ (as indicated by Table 1 which includes ranges of reported values of $4.5 \mathrm{ppm} /{ }^{\circ} \mathrm{C}$ or $35 \%$ of the mid-range value for carbon steel, $7,0 \mathrm{ppm} /{ }^{\circ} \mathrm{C}$ or $50 \%$ of the mid-range value for stainless steel 304 , and $11.2 \mathrm{ppm} /{ }^{\circ} \mathrm{C}$ or $75 \%$ of the mid-range for castiron).

Second, knowing only that a material is gagequality carbon steel, tungsten carbide or chromium carbide, the expanded uncertainty of the material's CTE is likely to be of the order of $10 \%$ or $1 \mathrm{ppm} /$ ${ }^{\circ} \mathrm{C}$.

Third, with information about chemical composition, the expanded uncertainty in the tabulated values of CTEs of a variety of standard-composition substances including metals, alloys and non-metallic materials are usually of the order of $6 \%$ to $9 \%$. (With this generalization, one should keep in mind that the standard reference data are usually for well-annealed specimens of a class of materials and sometimes includes an average over a range of compositions.)

Lastly, with direct measurements of CTEs obtained by dilatometry on particular specimens of materials with cocfficients in the range of, say, 3 $\mathrm{ppm} /{ }^{\circ} \mathrm{C}$ (such as silicon) to $23 \mathrm{ppm} /{ }^{\circ} \mathrm{C}$ (such as aluminum and its alloys), the expanded uncertainties in CTE are of the order of $0.3 \%$.

\section{Uncertainty in Temperature}

Uncertainty in the measurement of the length of a part also results from the uncertainty in the value of the temperature of the part, because the temperature must be measured and used to calculate the part dimension at the reference temperature. 


\subsection{Sensor-Limited Uncertainty in Temperature Measurement}

Table 6 shows representative limiting uncertain. ties, stated $\left(\Delta_{T}\right)$ and expanded $\left(U_{T}\right)$, associated with the use of the major types of NIST-calibrated temperature sensor systems for the determination of an object's temperature and, for reference, the absolute limit of temperature measurement at $20^{\circ} \mathrm{C}$. This limit is the $0.0002{ }^{\circ} \mathrm{C}$ expanded uncertainty of a primary calibration of a SPRT, which is also the uncertainty with which the melting point of gallium, a defining point on the Intcrnational Temperature Scale, can be realized [25].

In order of decreasing values, the stated (and expanded) uncertainties are: 1$) 0.1{ }^{\circ} \mathrm{C}\left(0.12^{\circ} \mathrm{C}\right)$ for a Type-T thermocouple with a reference junction in an ice bath and read-out with a digital voltmeter [26]; 2) $0.03^{\circ} \mathrm{C} \quad\left(0.035^{\circ} \mathrm{C}\right)$ for a visually-read mercury-in-glass thermometer $[26] ; 3) \quad 0.01{ }^{\circ} \mathrm{C}$ $\left(0.012^{\circ} \mathrm{C}\right)$ for well-selected glass bead thermistors [27]; 4) $0.002^{\circ} \mathrm{C}\left(0.0023^{\circ} \mathrm{C}\right)$ for Type-T thermocouples referenced directly against a standard platinum resistance thermometer (SPRT) in a temperature-controlled $20^{\circ} \mathrm{C}$ cell [28]; and 5) $0.001{ }^{\circ} \mathrm{C}\left(0.002^{\circ} \mathrm{C}\right)$ for one SPRT as sensor referenced against a second in a $20^{\circ} \mathrm{C}$ cell [25].

\subsection{Object Temperature Measurement}

Figure 2 shows schematically the types of locations at which temperature measurements are made: $(A)$ in the air (or liquid) medium surround. ing the object or part the temperature of which is to be determined; (B) on the walls of the temperature-control enclosure surrounding the measuring machine; (C) on the measuring machine; or (D) on the object itself.

Because combinations of radiation, convection, and conduction within this overall system can produce differential heating or cooling, the temperature of the part as a whole is not necessarily the

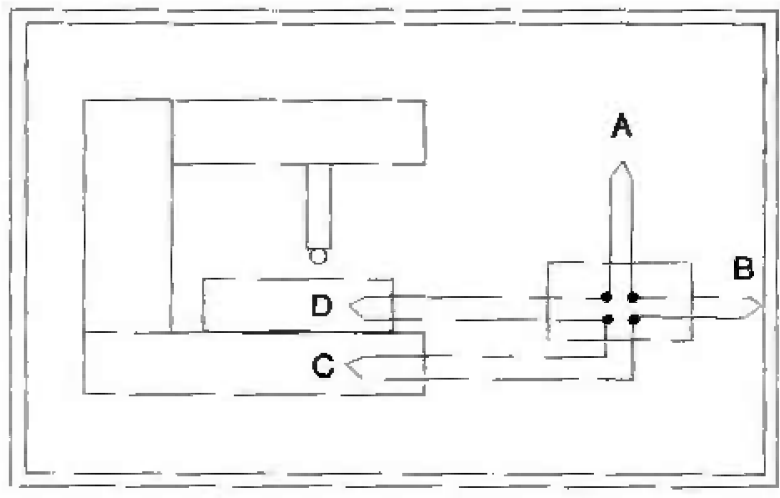

Flg. 2. Schentatic representation of altemative locations of temperature monitors: (A) air surrounding object; (B) enclosure walk; (C) machine; (D) object of measurement itself.

same as that of any these points of measurement, including a single point on the object. Uncertainty also results from nonuniformity of the temperature distribution over the part, or nonequilibrium of the part with the environment at which temperature is measured.

\subsection{State-of-the-Art Temperature Facilities}

Table 7 shows, for state-of-the-art measuring and manufacturing systerns, the stated temperature "stability" of each (taken to be the temporal variation about a mean temperature) and reported temperature "accuracy" (taken to be the stated uncertainty in that mean temperature). In each case, stated stabilities and accuracies are each treated as otherwise-unspecified single-component uncertainties obtained from quantities with uniform distribution and converted to expanded uncertainties by multiplication by 1.155 .

In the order of decreasing expanded uncertainty, these systems include: (1) conventional metrology facilities with temperatures controlled to $0.12^{\circ} \mathrm{C}$; (2) two commercial laser-interferometer microelectronics mask measurement systems with stabilities

Table 6. Stated $\left(\Delta_{r}\right)$ and expanded $\left(U_{T}\right)$ uncertainties in temperature measurement near $20^{\circ} \mathrm{C}$ altainable by standard platinum resistance, bead-in-glass thermistor, type-T thermocouple, and mercury-in-glass thermometers

\begin{tabular}{llllll}
\hline \hline Sensor & Reference & Instrument & Bath & $\Delta_{T}$ (stated) & $U_{T}$ (expanded) \\
\hline SPRT & Ga-Pt & & & $0.0001^{\circ} \mathrm{C}(\sigma)$ & $0.0002^{\circ} \mathrm{C}$ \\
SPRT & SPRT & Bridge & $20{ }^{\circ} \mathrm{C}$ Cell & $0.001^{\circ} \mathrm{C}(\sigma)$ & $0.002^{\circ} \mathrm{C}$ \\
TC & SPRT & Hridge & $20{ }^{\circ} \mathrm{C}$ Cell & $0.002^{\circ} \mathrm{C}$ & $0.0023^{\circ} \mathrm{C}$ \\
Thermisior & & Bridge & & $0.01^{\circ} \mathrm{C}$ & $0.012^{\circ} \mathrm{C}$ \\
Hg-glass & & & $0.03^{\circ} \mathrm{C}$ & $0.035^{\circ} \mathrm{C}$ \\
TC & & DVM & $0{ }^{\circ} \mathrm{C}$ Junc & $0.1^{\circ} \mathrm{C}$ & $0.12^{\circ} \mathrm{C}$ \\
\hline
\end{tabular}


Table 7. Temperature stabilities and uncertainties reported for various state-ofthe-art dimensional-measurement instruments and facilitjes.

\begin{tabular}{|c|c|c|c|}
\hline $\begin{array}{l}\text { Instrument/facility with } \\
\text { high-performance } \\
\text { temperature systcm }\end{array}$ & $\begin{array}{l}\text { Reported } \\
\text { "stability" }\end{array}$ & $\begin{array}{l}\text { Reported } \\
\text { "accuracy" }\end{array}$ & $\begin{array}{l}\text { Expanded } \\
\text { uncertainty }\end{array}$ \\
\hline $\begin{array}{l}\text { Primary-std linescalc } \\
\text { calibration }\end{array}$ & & $0.002^{\circ} \mathrm{C}$ & $0.00233^{\circ} \mathrm{C}$ \\
\hline $\begin{array}{l}\text { Large-optics-diamond- } \\
\text { turning machine }\end{array}$ & $0.006^{\circ} \mathrm{C}$ & $0.01{ }^{\circ} \mathrm{C}$ & $0.010^{\circ} \mathrm{C}$ \\
\hline $\begin{array}{l}\text { Primary-std-lab } \\
\text { CMM calibration }\end{array}$ & & $0.01{ }^{\circ} \mathrm{C}$ & $0.012^{\circ} \mathrm{C}$ \\
\hline $\begin{array}{l}\text { Commercial IC mask } \\
\text { metrology system }\end{array}$ & $0.01^{\circ} \mathrm{C}$ & & $0.012^{\circ} \mathrm{C}$ \\
\hline $\begin{array}{l}\text { Commercial IC mask } \\
\text { mettology system }\end{array}$ & $0.05^{\circ} \mathrm{C}$ & & $0.058^{\circ} \mathrm{C}$ \\
\hline $\begin{array}{c}\text { Conventional CMM } \\
\text { laboratory }\end{array}$ & & $0.1{ }^{\circ} \mathrm{C}$ & $0.12{ }^{\circ} \mathrm{C}$ \\
\hline
\end{tabular}

of $0.058{ }^{\circ} \mathrm{C}$ and $0.012^{\circ} \mathrm{C}$, respectively $[29,30]$; (3) Physicalish-Technische-Bundesanhalt's special metrology facility controlled to $0.012^{\circ} \mathrm{C}[31]$; (4) Lawrence-Livermore's Large Optics Diamond Turning system with a measured stability of its surrounding air environment of $0.001{ }^{\circ} \mathrm{C}$ and an expanded uncertainty of $0.012^{\circ} \mathrm{C}[32]$; and (5) NIST's Linescale Interferometer System with a temperature measurement expanded uncertainty of $0.0023^{\circ} \mathrm{C}[28]$.

\section{Thermal-Expansion Analyses of State- of-the-Art Engineering Measurement Systems}

Table 8 shows reported results of analyses of thermal expansion effects in three state-of-the-art engineering measurement systerns. The systems are: 1) a spectalized measuring machine for inspecting the mating features of the solid rocket motor of the U.S. Space Shuttle; 2) a commercial

Table 8. Stated incremental, fractional length and Iractional tolerance uncertainties compared to the Thermal Error Indices (TEI) for three state-of-the-art engineering measurcment systems

\begin{tabular}{|c|c|c|c|}
\hline & Rocket mutor sea! & CMM siep gage & $\mathrm{X}$-ray mask \\
\hline Dimension & $3650 \mathrm{~mm}$ & $1000 \mathrm{~mm}$ & $50 \mathrm{~mm}$ \\
\hline Materials & Aluminum/steel & Steel/Zcrodur & Silicon \\
\hline$a\left(\mathrm{ppm} /{ }^{\circ} \mathrm{C}\right)$ & $23.4 / 12.2$ & 11.50 .00 & 2.8 \\
\hline$\Delta_{\alpha}(\mathrm{ppm} / \mathrm{C})$ & $1.20 .6(5 \%)$ & $0.1 / 0.05$ & $(3 \%)$ \\
\hline$\left(T-T_{n}\right)$ & $\begin{array}{l}\text { Worst: } 11.1{ }^{\circ} \mathrm{C} \\
\text { ldeal: } 0^{\circ} \mathrm{C}\end{array}$ & $1^{\circ} \mathrm{C}$ & $0^{\circ} \mathrm{C}$ \\
\hline$\Delta_{T}$ & $\begin{array}{l}\text { Worst: } 0.9^{\circ} \mathrm{C} \\
\text { Ideal: } 0.36^{\circ} \mathrm{C}\end{array}$ & $0.1{ }^{\circ} \mathrm{C}$ & $0.01{ }^{\circ} \mathrm{C}$ \\
\hline$\tau$ & $127 \mu \mathrm{m}$ & $1.33 \mu \mathrm{m}$ & $15 \mathrm{~nm}$ \\
\hline$\Delta_{f-}$ & $\begin{array}{l}\text { Worst: } 95.3 \mathrm{\mu m} \\
\text { [deal: } 17.6 \mathrm{\mu m}\end{array}$ & $\begin{array}{l}\text { Stcel: } 1.80 / 1,27 \mu \mathrm{m} \\
\text { Z-dur: } 0.61 / 0.55 \mu \mathrm{m}\end{array}$ & 1 nm \\
\hline$\Delta_{L} / L$ & $\begin{array}{l}\text { Worst: } 27 \mathrm{ppm} \\
\text { Ideal: } 4.8 \mathrm{ppmn}\end{array}$ & $\begin{array}{l}\text { Steel: } 1.8 / 1.3 \mathrm{ppm} \\
\text { Z-dur: } 0.6 / 0.6 \mathrm{ppm}\end{array}$ & $0.02 \mathrm{ppm}$ \\
\hline$\Delta_{\mathrm{L}} / \tau$ & $\begin{array}{l}\text { Worst: } 75 \% \\
\text { Ideal: } 14 \%\end{array}$ & $\begin{array}{l}\text { Steel: } 135 \% / 96 \% \\
Z \text {-dur: } 46 \% / 41 \%\end{array}$ & $67 \%$ \\
\hline$T E I$ & $\begin{array}{l}\text { Worst: } 47 \% \\
\text { Ideal: } 12 \%\end{array}$ & $\begin{array}{l}\text { Steel: } 94 \% \\
\text { Zdur: } 4 \%\end{array}$ & $67 \%$ \\
\hline
\end{tabular}

